\title{
PROMOTING SOCIAL EQUALITY IN INCLUSIVE EDUCATION: MAPPING THE EXPERIENCE OF PARENTS OF CHILDREN WHO RELY ON AUGMENTATIVE AND ALTERNATIVE COMMUNICATION
}

\author{
Marianna Gregoriou', Eliada Pampoulou², George Milis ${ }^{1}$ \\ 1 EUROCY Innovations Ltd, Cyprus \\ ${ }^{2}$ Cyprus University of Technology, Cyprus
}

\begin{abstract}
Inclusive education aims for equal opportunities to be provided to all children regardless of their socioeconomic background, genre, or disability. There are various technological tools that can support the inclusive education of students with complex communication needs. Despite the fact that the parents' roles in supporting pupils with disabilities is vital, to date, there has been a lack of research investigating the roles of Cypriot parents of these children. The research aim was to explore the experiences of parents on the island who support students with complex communication needs, regarding how they perceive their roles as parents. In-depth interviews were conducted with six parents of children aged five to twelve years. Data were analysed based on thematic analysis. The findings show that parents of children with complex communication needs in Cyprus have a number of roles when it comes to supporting their children in communicating with others. They attend training sessions to acquire the necessary skills to communicate effectively with their children. They also act as communicating partners with friends, relatives and others. In addition, they act as advocates of their children both in the school, as well as in the wider community. It is vital that a number of online platforms are made openly available in order to increase knowledge and skills on issues related to AAC and inclusion. Of note is the MYHUB Inclusion Hub Platform (www.inclusion-hub.eu) which offers a one-stop-shop for inclusion practices, tools, resources and methods addressed to the pedagogical staff in formal and non-formal educational settings.
\end{abstract}

Keywords: augmentative and alternative communication, assistive technology, Cyprus, inclusive education, parents' experience, school collaboration. 


\section{Introduction}

Since the 1990s, pupils with disabilities have had the right to be educated alongside their peers in mainstream schools to a much greater extent than previously. Inclusive education refers to the right of all people to education that is, guaranteeing the presence, participation, and progress of all students by providing equal opportunities ("Article 24 - Education United Nations Enable" 2021). Inclusion often involve reforms that require new curricula, new teaching methods and accessible materials (Sheehy et al., 2013). The different technological tools can support the inclusive education of pupils, in particular those who find it difficult or are unable communicate with their peers in classrooms through speech. The field of Augmentative and Alternative Communication (AAC hereafter) focuses on a variety of unaided (such as nodding, gestures, and sign language) and aided forms of communication such as talking products, tablets as well as Speech Generating Devices (SGD).

Several studies have emphasised the importance of the parental role when designing services provision for people with disabilities, such as through family centre intervention (An, Chan \& Kaukenova, 2018); the need for creating parent professional partnerships (Dunst and Paget, 1991); and family support service plans (McBride et al., 1993. For the case of Cyprus, Phtiaka (2007) held that, for parental education to be effective it needs to be considered in terms of partnerships. This is because parents are partners in knowledge and skills as well as a valuable source of information. As the same author commented, by not considering parents in the process of supporting their child's communication skills, this will lead to inefficient intervention practices and this has negative effect on child progress, whilst also putting the family under a lot of stress. Addressing this issue in 2016, the Equality and Social Inclusion Through Positive Parenting (ESIPP) project explored the training needs that Cypriot, Croatian and Macedonian parents need in order to support their child who is on the autism spectrum (Preece et al., 2016). A series of modules was developed aimed at providing greater understanding of the autistic condition, and promoting a range of strategies that can be implemented to help in addressing some of the many needs these children and their families face. ("Parent Education Programme - ESIPP" 2021). To support their children effectively, parents need to undertake different roles such as taking decisions regarding the technological tools, development of different activities and providing recommendations to others (Light and McNaughton's, 1993). Estrella investigated the demands placed on a nursing student and a mother of two children with autism spectrum disorder, from which they proposed "a six-stage model designed to help also other 
parents move from the sense of bewilderment that often follows a diagnosis of autism to a sense of empowerment" (Estrella, 2013).

Despite the fact that the parents' roles in supporting pupils with disabilities is vital, to date, there has been a lack of research investigating the roles of Cypriot parents of children with complex communication needs. Hence, the research aim was to explore the experiences of parents on the island who support students with limited or no functional speech, regarding how they perceive their roles as parents.

\section{Method}

In order to explore in-depth the parents' experiences of children who use AAC a phenomenological approach was chosen as it focuses on peoples' lived experiences regarding a specific phenomenon (van Manen, 1990). Specifically, the phenomenology of van Manen (1990) was chosen as the context of this research was pedagogical; focusing on children who attend school. The participants were selected through purposive sampling.

Participants: Participants were selected via snowballing sampling. The selection criteria for participation were that they were the parents of individuals aged five to thirteen years old, who were AAC users. In total, six parents participated in the study, all of whom were mothers.

Table 1 shows the description of the children that these participants support and who use AAC methods to communicate with others. The decision to focus on data collection from a small sample was driven by the perspective under phenomenological research that, in order to be able to analyse in-depth peoples' lived experiences a small sample is warranted (van Manen, 1990; 2014).

Table 1. Description of the AAC users

\begin{tabular}{|l|l|l|l|l|l|l|}
\hline Cases & Case 01 & Case 02 & Case 03 & Case 04 & Case 05 & Case 06 \\
\hline Gender & Boy & Boy & Boy & Boy & Girl & Boy \\
\hline $\begin{array}{l}\text { Age } \\
\text { (years) }\end{array}$ & 13 & 6 & 13 & 5 & 8 & 5 \\
\hline $\begin{array}{l}\text { Medical } \\
\text { Diagnosis }\end{array}$ & $\begin{array}{l}\text { Moebius } \\
\text { Syndrome }\end{array}$ & $\begin{array}{l}\text { Inherited } \\
\text { Metabolic } \\
\text { Disease } \\
\text { (IMDs) }\end{array}$ & $\begin{array}{l}\text { Cerebral } \\
\text { Palsy, } \\
\text { Hearing } \\
\text { deficiency }\end{array}$ & $\begin{array}{l}\text { Micro- } \\
\text { cephalia }\end{array}$ & $\begin{array}{l}\text { Cerebral } \\
\text { Palsy }\end{array}$ & $\begin{array}{l}\text { Develop- } \\
\text { mental } \\
\text { Delay }\end{array}$ \\
\hline Education & $\begin{array}{l}\text { Primary } \\
\text { school }\end{array}$ & $\begin{array}{l}\text { Nursery } \\
\text { school }\end{array}$ & $\begin{array}{l}\text { Primary } \\
\text { school }\end{array}$ & $\begin{array}{l}\text { Nursery } \\
\text { school }\end{array}$ & $\begin{array}{l}\text { Primary } \\
\text { school }\end{array}$ & $\begin{array}{l}\text { Nursery } \\
\text { school }\end{array}$ \\
\hline $\begin{array}{l}\text { AAC } \\
\text { System }\end{array}$ & $\begin{array}{l}\text { SPG } \\
\text { device }\end{array}$ & $\begin{array}{l}\text { Eye gaze } \\
\text { system }\end{array}$ & $\begin{array}{l}\text { Eye gaze } \\
\text { system }\end{array}$ & $\begin{array}{l}\text { SPG } \\
\text { device }\end{array}$ & $\begin{array}{l}\text { SPG } \\
\text { device }\end{array}$ & $\begin{array}{l}\text { Talking } \\
\text { Pen }\end{array}$ \\
\hline
\end{tabular}




\section{Data Collection and Analysis}

The instrument used was semi-structured interviews. An aide-memoire was used in order to guide the topics for the interviews and participants were also encouraged to share their experiences on matters related to the research questions. Examples of the questions asked during the interviews were:

1. What roles did you need to undertake in order to support your child's communication needs?

2. Did you anticipate any challenges during this process and if yes, what were these?

3. How did you overcome those challenges? In order to collect in-depth understanding about participants' experiences two interviews occurred with each.

The first author kept a reflective journal in which she noted her pre-understandings about the topic, data collection and the subsequent data analysis. Thematic analysis was employed in order to identify the themes relating to parents' experiences in supporting AAC users (van Manen, 1990).

\section{Results}

The findings show that parents of children with complex communication needs in Cyprus have a number of roles when it comes to supporting their children in communicating with others, which are discussed in the following paragraphs.

\section{AAC knowledge acquisition through training}

The findings show that one of the parents' roles was to undertake several training courses in order to acquire the necessary skills to support their child. Training had been received from different sources, such as attending conferences, assistive technology workshops, participating in speech therapy sessions and engaging with suppliers in the assistive technology field. One of the mothers, Christina, commented that she goes everywhere with her husband: to training, conferences and generally, to any event where they can learn about AAC. As she commented, "whenever we find out that someone will come from abroad, such as a doctor, a psychologist, we go". She also added that in the past few years she has been receiving consultation services from AAC specialists, such as training on how to create symbolised resources on her son's AAC tablet. Kiki and Despina mentioned that, for them, receiving training on the eye-gaze system was important. More specifically, Kiki said, "I am going to attend training with my son's speech and language therapist on how to use his eye-gaze system and create materials on it". Despina commented that when she bought the 
eye-gaze system for her child she paid the company to get extra training, as it was important for her to understand how to use it with her child.

Furthermore, participants expressed that having the necessary skills is important as they can transfer this knowledge to their child. As Georgia said, "I asked to receive training on AAC, on how to use the device, because as a parent I felt that I could be the link to transfer the knowledge to the child ... I got trained with the speech and language therapists who trained the child". As discussed in the literature, parents face many challenges related to learning AAC technology. In McNaughton and colleagues (2008) study, it was stated that parents who have good skills using personal computers report most successful experiences. Parents engage with different types of training in order to acquire the necessary skills to be able to support their child reliant on AAC. In Bruno and Dribbon's (1998) study, parents were trying to gain technology and interaction skills for working with their children who lacked verbal skills by attending a special camp. That camp's aim was to support them in improving their communication interactions with their children using AAC devices via different activities.

\section{Resources development}

The findings show that parents took full responsibility for developing resources for their children's communication devices. As Christina stated, "I develop materials every week, depending on the programme of the school. For example, if they have winter as a subject, I will find the symbol for snow, the jacket, they will give us a list of words from school ... so my son can have these pictures and he would use them to show them and participate in the class". Similarly, Georgia had taken full responsibility for creating resources for her twelve-year-old son, who was attending mainstream classes three times per week. As she declared, "I need to prepare symbolised resources so he can communicate in class". The reason that parents were developing these resources was because the school staff did not see it as being their responsibility. As Georgia said "I had to take the part for AAC intervention as the school would not take on this role. So, I took this role, in order to support my child's progress". Another reason relates to the knowledge that school staff had on issues surrounding the AAC field. As Christina commented, "the teachers are really young without any experience, so they can't and neither have an idea on how to support the child and they ask for our speech and language therapist, from the private sector, to help regarding how to deal with my child". Pampoulou and colleagues (2018) found that AAC services provision by speech and language therapists working in the public Cypriot schools are constrained and that there is still much room for improvement. 


\section{Discussion}

The current study was aimed at exploring the parents' views on supporting their children who communicate via different AAC systems. The findings have revealed that they undertake training to acquire the necessary skills and knowledge needed to be able to support their children who are AAC users. These skills are mostly focused on developing AAC resources for the aided modes of communication of their children as they believe that school staff are not in the position to support students regarding this aspect of intervention. Pampoulou and colleagues (2018) found that AAC practices in Cyprus are still in their infant stages. It is also recommended that the different available academic programmes should place an emphasis on providing adequate training to specialists. It is also vital that a number of online platforms are made openly available in order to increase knowledge and skills on issues related to AAC and inclusion. The MYHUB Project (www. inclusion-hub.eu) with its Platform for inclusion practices, tools, resources and methods for the pedagogical staff in formal and non-formal educational settings. It aims to improve the knowledge, skills (including advocacy skills) and competences of the pedagogical staff, to promote implementation of inclusive learning practices based on the know-how provided from countries with greater experience in this regard. ("MyHub" 2021).

\section{Conclusions}

In conclusion, this research highlights that a holistic approach is vital when designing interventions for AAC users in which all parties (e. g. parents, teachers, therapists, AAC users) involved play an important role. This will eventually lead to successful intervention outcomes. It is acknowledged that further research is necessary on this particular topic, not only from the perspective of the parents, but also, from all parties involved in order to identify all the essential elements for successful services provision to AAC users. Amongst others, this will also help to decide on the training needs of all parties involved so to increase their knowledge, skills with the ultimate goal of successful intervention outcomes.

\section{References}

An, S., Chan, C., \& Kaukenova, B. (2018). Families in Transition: Parental Perspectives of Support and Services for Children with Autism in Kazakhstan. International Journal of Disability, Development and Education, 67(1), 28-44. https://doi: 10.1080/ 1034912x.2018.1499879

Bruno, J., \& Dribbon, M. (1998). Outcomes in AAC: Evaluating the effectiveness of a parent training program. AAC Augmentative and Alternative Communication, 14(2), 59-70. https://doi.org/10.1080/07434619812331278216 
Dunst, C. J., \& Paget, K. D. (1991). Parent-professional partnerships and family empowerment, In M. J. Fine (Ed.), Collaboration with parents of exceptional children. Brandon, VT, US: Clinical Psychology Publishing Co, pp. 25-44.

Estrella, C. (2013). Parental perspectives on the care of children with autism. Learning Disability Practice, 16(9), 24-28. https://doi: 10.7748/ldp2013.11.16.9.24.e1446

Light, J., \& McNaughton, D. (1993). Literacy and augmentative and alternative communication (AAC): The expectations and priorities of parents and teachers. Topics in Language Disorders, 13(2), 33-46. https://doi.org/10.1097/00011363-199302000-00005

McBride, S., Brotherson, M., Joanning, H., Whiddon, D., \& Demmitt, A. (1993). Implementation of family-centered services: Perceptions of families and professionals. Journal of Early Intervention, 17(4), 414-430. https://doi.org/10.1177/105381519301700406

McNaughton, D., Rackensberger, T., Benedek-Wood, E., Krezman, C., Williams, M., \& Light, J. (2008). A child needs to be given a chance to succeed: Parents of individuals who use AAC describe the benefits and challenges of learning AAC technologies, Augmentative and Alternative Communication, 24 (1), 43-55.

MyHub - ONE-STOP-SHOP on INCLUSION practices, tools, resources and methods for the pedagogical staff at formal and non-formal educational institutions. (2021). https:// www.inclusion-hub.eu/.

Pampoulou E, Theodorou, E., \& Petinou K. (2018). The use of augmentative and alternative communication in Cyprus: findings from a preliminary survey, Child Language Teaching and Therapy 34(1), 5-21. https://doi.org/10.1080/07434610701421007

Parent education programme. ESIPP. (2021). http://esipp.eu/parent-educationprogramme/.

Phtiaka, H. (2007). "Educating the other: A journey in Cyprus time and space" In Barton, L. and Armstrong, F., eds. Policy, experience and change, cross cultural reflections on Inclusive Education. London: Springer Books.

Preece, D., Symeou, L., Stošić, J., Troshanska, J., Mavrou, K., Theodorou, E., \& Frey Škrinjar, J. (2016). Accessing parental perspectives to inform the development of parent training in autism in south-eastern Europe. European Journal of Special Needs Education, 32(2), 252-269. https://doi: 10.1080/08856257.2016.1223399

Sheehy, K., Rix, J., Fletcher-Campbell, F., Crisp, M. \& Harper, A., (2013). Conceptualising inclusive pedagogies: evidence from international research and the challenge of autistic spectrum disorder. Erdelyi Pszichologiai Szemle (Transylvanian Journal of Psychology, $\mathrm{XIV}(1)$.

United Nations. (2021.). Article 24 - EDUCATION Enable. United Nations. https:// www.un.org/development/desa/disabilities/convention-on-the-rights-of-persons-withdisabilities/article-24-education.html.

Van Manen, M. (1990), "Researching lived experience: human science for an action sensitive pedagogy" London: Althouse Press.

Van Manen, M., (2014). Phenomenology of practice: meaning-giving methods in phenomenological research and writing. Walnut Creek, CA: Left Coast Press. 